A Journal of Culture, English Language, Teaching \& Literature ISSN 1414-3320 (Print), ISSN 2502-4914 (Online)

Vol. 17 No. 1; July 2017

Copyright (c) Soegijapranata Catholic University, Indonesia

\title{
Motivational Teaching Strategies in Indonesian EFL Writing Classrooms
}

\section{Yustinus Calvin Gai Mali}

English Language Education Program, Faculty of Language and Arts, Universitas Kristen Satya Wacana, Indonesia

email: yustinus.calvin@staff.uksw.edu

Received: 02-03-2016 Accepted: 20-07-2017 Published: 11-08-2017 


\title{
Motivational Teaching Strategies in Indonesian EFL Writing Classrooms
}

\author{
Yustinus Calvin Gai Mali \\ yustinus.calvin@staff.uksw.edu \\ English Language Education Program, Faculty of Language \\ and Arts, Universitas Kristen Satya Wacana, Indonesia
}

\begin{abstract}
This qualitative study explores motivational teaching strategies employed in English as a foreign language (EFL) writing classrooms and designs a sample of lesson plans elaborating the strategies that were reflected from open-ended questionnaires of sixty-five first-year students at English Language Education Program in a private university in Indonesia. The data analysis reveals possible motivational strategies that are classified into Dornyei's (2001) framework of motivational teaching practice. Based on the analysis, the study reinforces a view that teachers can motivate their students to learn and they use particular teaching strategies to motivate their students. Eventually, this study hopes to provide insights for EFL teachers espousing similar teaching practices, so they can enhance their students' motivation, particularly in their EFL writing classrooms.Key words: motivational teaching strategies, motivation, EFL writing, EFL teachers
\end{abstract}

Abstrak: Kajian kualitatif ini menyelidiki strategi pengajaran
motivasional yang diterapkan pada kelas menulis Bahasa Inggris
sebagai Bahasa Asing dan merancang suatu contoh rencana
pembelajaran yang mengelaborasikan strategi pengajaran tersebut yang
direfleksikan melalui angket terbuka dari enam puluh lima mahasiswa
baru pada Program Studi Pendidikan Bahasa Inggris di suatu
Universitas Swasta di Indonesia. Analisa data menunjukan beberapa
strategi pengajaran motivasional yang diklasifikasikan dalam kerangka
praktek pengajaran motivasional milik Dornyei (2001). Berdasarkan
analisa tersebut, kajian ini menguatkan suatu pandangan bahwa guru
dapat memotivasi siswanya untuk belajar dan mereka menggunakan
strategi pengajaran tertentu untuk memotivasi siswanya. Pada 
akhirnya, kajian ini berharap untuk dapat memberikan wawasan bagi guru Bahasa Inggris sebagai Bahasa Asing yang mempunyai praktek pengajaran serupa sehingga mereka dapat meningkatkan motivasi belajar siswanya, khususnya dalam kelas menulis Bahasa Inggris sebagai Bahasa Asing mereka.

Kata kunci: strategi pengajaran motivasional, motivasi, menulis Bahasa Inggris sebagai Bahasa Asing, guru Bahasa Inggris sebagai Bahasa Asing

\section{INTRODUCTION}

Some possible factors can ensure students' success in their English as a Foreign Language (EFL) learning, particularly in their Indonesian EFL writing classrooms, as the primary focus of the current study. One can be ascribed to students' motivation explaining, "why they decide to do something, how hard they are going to pursue it and how long they are willing to sustain the activity" (Dornyei, 2001, p.7). Undeniably, motivation roles as one of primary determinants of students' learning achievement (Dornyei, 1994; Harmer, 2007; Reid, 2007), including a success of their language learning (McDonough, 1983; Ellis, 1994; Kimura, Nakata, \& Okumura, 2000; Gass \& Selinker, 2001; Alsayed, 2003; Lifrieri, 2005; Khamkhien, 2010). "Without sufficient motivation, the brightest learners are even unlikely to persist long enough to attain any useful language proficiency" (Dornyei \& Cheng, 2007, p.153). Therefore, particularly in the context of EFL writing, any attempts to find out insights into what motivates students to write is an important issue to consider (Tran, 2007).

The current study is a follow-up to my Indonesian's investigation (Mali, 2015) that regarded positive teacher's performance as the main factor that motivated students to learn in their Indonesian EFL writing classroom. The students mentioned that their teacher, for instance, cared for them, could teach them enthusiastically, and always started the class with a prayer. Therefore, in this current study, I reinforce that teachers can motivate their students to learn (Dornyei \& Csizer, 1998; Chambers, 1999 in Dornyei, 2001; Oxford, 1998 in Dornyei \& Ushioda, 2001; Harmer, 2007) and believe in an underlying assumption that they use strategies to motivate their students (Astuti, 2013), which henceforth I call as motivational teaching strategies. In this study, adapting ideas from Dornyei (2001), Schunk, Pintrich, and Meece (2008); Kassing (2011); Mali (2015), I define the term motivational teaching strategies as steps or techniques used by teachers to 
enhance their students' motivation to write in English. They are also motivational influences that are consciously used to achieve some enduring positive effects, such as to keep students writing and to help them complete their writing tasks.

A spate of international studies has explored some motivational teaching strategies that teachers employ particularly in EFL contexts, a situation in which people learn English in a formal classroom with limited opportunities to use the language outside their classroom (Richards \& Schmidt, 2010). For instance, Alsayed (2003) concluded his study by suggesting ways to improve students' motivation level, such as by giving students' positive feedback and rewards, increasing their self-esteem and confidence.

Rost (2006) theorizes three layers of motivation in language learning from which teachers can tap to help them become a motivating teacher. The first layer is to find learners' passion for their goals in life, things they care about most and things that move them emotionally. In that case, teachers can help them to bring their passion into their classroom by introducing such hot elements as movies, songs, games, that can trigger their real interests, by organizing class activities around their theme of self-expression, by using teachers themselves as a model of enthusiasm and motivation for their students' learning.

The second layer is to change learners' reality. Learners, within EFL settings, need more language instructions outside the classroom from which they can maintain a sufficiently strong connection to the target language and build their motivation for learning. Therefore, it is necessary for teachers to help their students find more opportunities for doing their outside classroom learning, which can be done, for example, by directing them to quality language learning websites, developing an accessible library for them, and providing them with self-access quizzes, worksheets, and games.

The third layer is to connect to learning activities. It illustrates students' engagement, intention, attention, and memory in an activity that teachers have prepared. Rost (2006) suggests some connecting principles that he employed in his teaching materials. For instance, teachers should make each learning activity as vivid and tangible as possible by using provocative topics, including visual aids to engage students' attention. Besides, they can provide various learning activities in which their students can try different learning styles. It is also important for teachers to give feedback to their 
students covering all levels of their language progress, for elements of performance that affect their motivation, such as their success in an activity and their engagement level.

Cheng and Dornyei (2007) explored other motivational teaching strategies. As a modified replication of Dornyei and Csizer's (1998) Hungarian investigation, they involved three hundred and eighty-seven Taiwanese teachers of English and asked them to rate a list of forty-eight comprehensive motivational strategies dealing with how much importance they attached to the strategies and how often they implemented them in their day-to-day teaching practice. The results of the study would seem to indicate four motivational strategies; displaying motivating teacher behavior, promoting learners' self-confidence, creating a pleasant classroom climate and presenting tasks properly.

In Oman, Al-Mahrooqi, Abrar-ul-Hassan, and Asante (2012) carried out a more recent study to explore motivational teaching strategies as perceived by two hundred and eighty-six EFL practitioners teaching in public schools, colleges, and universities in all Oman regions. As a modified replication of Cheng and Dörnyeie's (2007) Taiwanese study, they asked their research participants to rate forty-eight strategies based on the importance and the frequency with which they used the strategies in their particular teaching contexts. Based on their data analysis, they found that teachers' performance in their classroom, such as setting a personal example with their behavior and promoting learners' self-confidence, is perceived as frequent motivational strategies by the research participants.

Concerning Indonesian and Chinese learners, Lamb and Wedell (2013) undertook a large-scale study to explore perspectives of fourteen twenty-two-year old learners about their inspiring English teacher. More specifically, the participants were Indonesian learners from fifty-five state schools and Chinese learners from ninety schools and six universities in Guangzhou. Their study showed that Indonesian learners valued clear and comprehensible lessons and teaching practices in a fun atmosphere but within a structure of the discipline. Meanwhile, Chinese students appreciated hard-working teachers who advised them and encouraged them to take specific steps to learn.

At the same year, Astuti (2013) conducted a case study in two different high schools; an international standard high school and a local high school, in a town in West Sumatra, Indonesia. She attempted to explore teachers and learners' perceptions of motivational teaching strategies so that she could investigate a connection between the strategies and their impacts on learners' learning motivation. The study suggests teachers to have a warm and 
encouraging manner as it is considered as a motivating factor in the classroom learning. Besides, the study highlights a relaxing atmosphere as a key factor for success in foreign language learning. In that case, teachers need to ensure that a learning environment is safe for students to learn a new language, so they can have the initiative to talk. With similar beliefs, "learning is easiest, most meaningful, and most effective when it takes place in a non-threatening situation" (Gage \& Beliner, 1992, pp. 480-485, as cited in Lopez, 2011, p. 54) mention) and creating a relaxed classroom atmosphere is seen as a motivational factor in an Indonesian EFL writing classroom (Mali, 2015).

Within this present study, I address some gaps in research related to the motivational teaching strategies. The previous related studies that I have reviewed seem to focus on exploring the strategies generally towards students' EFL learning. To the best of my knowledge, I still found very limited studies that sought to examine the strategies to learn a particular English language skill, such as writing regarded as a way of learning that can improve students' academic performance (White, 1986) and "an efficient tool to facilitate and to reinforce other language skills" (Hughey, Wormuth, Hartfiel, \& Jacobs, 1983, p. 6).

Therefore, the primary purpose of this study is to explore teachers' motivational teaching strategies employed in EFL writing classrooms without providing research participants with items of motivational teaching strategies for which they need to rate (Cheng \& Dornyei, 2007; Al-Mahrooqi, Abrar-ulHassan, \& Asante, 2012). The aim of the study can be achieved by asking students to reflect their teachers' teaching practices that they perceived to be motivating for them. Furthermore, the study aims to design a sample of lesson plans involving motivational teaching strategies emerged from the students' reflection. The lesson plan hopes to provide clear and practical illustrations on what teachers did to motivate their students, which seemingly has not been done by the previous related studies.

On one hand, I clearly understand that "certain motivational strategies are culturally dependent" (Cheng \& Dornyei, p.171), language learning situations can be varied from one to another (Dornyei, 2001), and "teaching is sometimes said to be situated and can only be understood within a particular context" (Richards, 2015, p.106). Nevertheless, I still maintain that the current study can suggest applicable teaching strategies that possibly help EFL teachers espousing similar teaching practices to enhance students' motivation, particularly in their EFL writing classrooms. 


\section{METHODOLOGY}

The current study attempts to explore students' perspectives on their teachers' motivational teaching strategies employed in Indonesian EFL writing classrooms. It was clear, therefore, that I needed to collect personal responses from research participants that indicated my limited control over the exploration (Malilang, 2013). Therefore, I conducted a qualitative study that aims to hear silenced voices about particular issues (Creswell, 2007), so the study could help me to understand social phenomena as perceived by human participants who were involved in the study (Ary, Jacobs, \& Sorensen, 2010). In particular, I approached the study using a content analysis that defines "the process of summarizing and reporting written data" (Cohen, Manion, Morrison, 2007, p.475).

\section{A. Research participants}

Considering the accessibility to conduct the study, I involved sixty-five freshmen from three of five EFL writing classes held in the first semester, academic year 2015/2016 at English Language Education Program of a private university in Indonesia. The numbers of the participants are not to be considered as a mean to generalize the results to a larger population. In this case, I hope that exploring the motivational teaching strategies since the beginning of the semester also provides an initial understanding of the strategies that teachers in the classrooms can use in enhancing their students' motivation in writing classes held in the upper semesters. Importantly, to keep the confidentiality of the current study, I kept names of the participants in initials.

\section{B. Research Setting}

In brief, the writing class, as the context of the current study, is one of language skill courses offered in the first semester at the study program. In that course, students learn English language aspects through creative writing in the forms of poems and a biography. At the end of the course, they are expected to possess some competencies, such as [a] to identify some features and language aspects addressed in poems, $[\mathrm{b}]$ to write some kinds of poems, such as metaphor, acrostic, narrative, and haiku, [c] to identify elements of sentence and paragraph writing, and [d] to write several kinds of paragraphs on various topics. Some other competencies are [e] to understand and to identify a generic structure of a biography, some language aspects addressed 
in biography and, [f] to write one biography. Therefore, motivational teaching strategies discussed in this study were limited to the strategies the teachers used to motivate their students to write particularly based on the competencies mentioned above.

\section{Data collection technique}

To begin with, I constructed an open-ended questionnaire, which allows research participants to provide a detailed and an unlimited number of responses (Neuman, 2006) and which consists of a statement and two questions developed from Kassing, 2011; Astuti, 2013; Mali, 2015. They are [1] tell about any motivational teaching strategies your teacher uses when $\mathrm{s} /$ he teaches you in the classroom; [2] how do you respond to the strategies that your teacher uses in the classroom?; [3] to what extent do those strategies help to motivate you to write in English and to help you complete your writing tasks? Considering the English language proficiency of the research participants as the freshmen, I provided Indonesian translations of the items [1-3] and allowed the participants to respond them using their first language, Bahasa Indonesia (L1). It was also done for I needed to ensure that they could completely understand those three items and, therefore, provide clear responses to the questionnaire.

Before data collection activities, $\mathrm{I}$ piloted the questionnaire in my class to "assess the appropriateness of the data-collection methods and make changes if necessary" (Ary, Jacobs, \& Sorensen, 2010, p.95), so I could ensure that the items on the questionnaire were understandable. Then, I met teachers of the classrooms, explained the purpose of the study, and asked their permissions to distribute the questionnaire. Obtaining their permission, I proceeded to administer the questionnaire to the participants on the first week of November 2015. To delve deeper information about the issues, I read their responses written on the questionnaire and circled some ideas that they needed to clarify further. On the third week of November 2015, I redistributed the questionnaire and asked the participants to clarify further their circled responses. Within a week period, they submitted the questionnaire to their teachers from whom I obtained back all questionnaires to be analyzed. I excluded ten of sixty-five questionnaires because their responses were not related to the motivational teaching strategies and did not further clarify the circled responses.

\section{Data analysis technique}


The written responses to the questionnaire were analyzed using a content analysis that defines a process of summarizing, reporting written data, and examining emergent nature of themes from the data (Cohen, Manion, \& Morrison, 2007). More specifically, I read all the written data and underlined some responses indicating the motivational teaching strategies. Initially, I quantified the strategies analyzed from the data and put them in a Table to provide an overview of the teaching strategies. Then, adapting what Astuti (2013) has successfully done, I classified the analyzed responses into four main themes underpinned by Dornyei's (2001) integrated framework of motivational teaching practice, which is regarded as a comprehensive framework (Cheng \& Dornyei, 2007) and has been developed for educational applications. In each theme, some excerpts of the written responses from the questionnaire were provided to support the discussions of the study. I presented excerpts of responses written in English as they were without any editing to maintain their truth-value (Sawir, 2005). Yet, I translated excerpts of responses written in the participants' L1 to ensure the clarity of the information for international readers. Finally, any motivational teaching strategies emerged in the themes were practically implemented in a sample of lesson plans that I expect to provide EFL teachers with applicable and practical ideas that they can adapt to enhance their students' motivation.

\section{FINDINGS AND DISCUSSION}

I discuss motivational teaching strategies reflected from the written responses to the questionnaire and provide an overview of the strategies in a Table. Then, the strategies displayed in the table were classified into four main themes based on Dornyei's (2001) integrated framework, namely:

(1) creating the basic motivational conditions,

(2) generating initial motivation,

(3) maintaining and protecting motivation, and

(4) encouraging positive retrospective self-evaluation.

The themes help to illustrate what the teachers did in the classrooms to motivate their students to write. In essence, I found 120 statements indicating the motivational teaching strategies used in the classes. I summarized them in Table 1 below. 
Table 1:

An overview of the motivational teaching strategies

\begin{tabular}{clcc}
\hline No & \multicolumn{1}{c}{ Cited Motivational Teaching Strategies } & Number & Percentage \\
\hline 1. & $\begin{array}{l}\text { walking around the class to explain a } \\
\text { learning material to a student directly and } \\
\text { to give him/her feedback }\end{array}$ & 11 & $12,95 \%$ \\
\hline 2. & $\begin{array}{l}\text { re-explaining the learning materials that } \\
\text { the students still do not understand }\end{array}$ & 11 & $12,95 \%$ \\
\hline 3. & utilizing some supporting technologies & 10 & $11,78 \%$ \\
\hline 4. & asking students to work in a group & 9 & $10,58 \%$ \\
\hline 5. & making jokes & 9 & $10,58 \%$ \\
\hline 6. & $\begin{array}{l}\text { asking students to do a peer feedback } \\
\text { activity }\end{array}$ & 8 & $9,41 \%$ \\
\hline 7. & $\begin{array}{l}\text { chatting with the students in the } \\
\text { classroom }\end{array}$ & 6 & $7,06 \%$ \\
\hline 8. & sharing learning strategies to the students & 6 & $7,06 \%$ \\
\hline 9. & $\begin{array}{l}\text { calling every student to show his/her } \\
\text { written work }\end{array}$ & 4 & $4,72 \%$ \\
\hline 10. & $\begin{array}{l}\text { giving questions for each student to review } \\
\text { the learning materials }\end{array}$ & 3 & $3,52 \%$ \\
\hline 11. & starting the class with a prayer & 3 & $3,52 \%$ \\
\hline 12. & $\begin{array}{l}\text { asking students to greet and smile at each } \\
\text { other }\end{array}$ & 2 & $2,35 \%$ \\
\hline 13. & playing songs & 2 & $2,35 \%$ \\
\hline 14. & sharing an experience of studying abroad & 1 & $1,17 \%$ \\
\hline & TOTAL & 85 \\
\hline
\end{tabular}

The strategies in Table 1 were discussed and classified into four main themes in the subsequent parts.

\section{A. Creating the Basic Motivational Conditions}

Dornyei (2001) mentions three interrelated conditions to enhance students' learning motivation. The first condition is showing appropriate teacher behaviors and possessing a good relationship with students. To have a positive relationship with their students, teachers can show a sense of acceptance to their students, listen and pay attention to each of them, and be available for a personal contact. S7 shares her experience.

\section{Excerpt 1}


My teacher likes to give questions for each student related to learning materials that he has explained. He aims to ensure that all students clearly understand his explanation. Besides, he is never angry. He also cares for his students, so they feel comfortable. He always greets us, asks the progress of our study, and if we have gone to the church. Moreover, when I cannot see him, I can ask him questions through his blog. (S7/ID1)

Teachers also need to show their commitment to their students' academic progress. For instance, they should provide concrete assistance, respond immediately when their students need their help, offer to meet their students individually to explain things, and show concern when things are not going well (Dornyei, 2001). This concern is reflected in the responses of S8, S16, and S22 that observe how their teacher walks around the class, calls them one by one to read their written work, and provides them with feedback, which Richards and Lockhart (1996) believe as an essential aspect of teaching.

\section{Excerpt 2}

In his classroom, he is willing to walk around the class to explain a learning material to a student directly. It is very effective as a student can freely ask the material that $\mathrm{s} /$ he probably still does not understand. This technique motivates me. (S8/ID2)

\section{Excerpt 3}

My teacher often walks around our desks to see whether what we have done is right. In some occasions, he asks every student to come to his table in front of the class and to show his/her written work. He will tell the student if there is something to improve. For instance, when I write supporting ideas in a paragraph, he tells me that some of the sentences are not related to the topic sentence in the paragraph. He asks me to revise them. (S16/ID3)

\section{Excerpt 4}

She always gives us feedback. She called us one by one. Personally, she gave us feedback like: "your biography is quite shallow. You should add more information to it." She cares many details. (S22/ID4) 
Excerpts $2-4$ can be practical illustrations on giving positive feedback to students as a way to improve their motivation level (Alsayed, 2003). Dornyei (2001) explicates that it is necessary for teachers to show their enthusiasm by, for instance, sharing their personal interest in learning English and showing their students that they value English learning as a meaningful experience that can satisfy and enrich their life. This strategy is seemingly done by a teacher in the writing class as what S47 writes in her questionnaire.

\section{Excerpt 5}

My teacher always motivates us by sharing her experience when she was in the States. Her experience teaches us to be able to think critically and maturely. (S47/ID5).

In a sense, excerpt 5 can be a demonstration of a motivating teacher behavior that Cheng and Dornyei (2007) believe as one of strategies to motivate students to learn. It also illustrates how teachers set a personal example of their behavior as a way to motivate their students to learn (Al-Mahrooqi, Abrar-ul-Hassan, \& Asante, 2011). Nevertheless, it is important to bear in mind that students can think the expressions of enthusiasm and motivating personal examples by a teacher differently as they probably have different cultures from their teacher (Dornyei, 2001).

The second motivational condition is creating a pleasant and supportive classroom atmosphere. Teachers can do it by possessing a good rapport with their students and by explaining to students that making mistakes is a part of learning. Therefore, students can feel comfortable to take risks, as they know that they will not be criticized when they make a mistake. With a similar view, Harmer (2007) reinforces the essence of having a good student-teacher rapport that "Students are far more likely to stay motivated over a period of time if they think that the teacher cares about them. This can be done by building good teacher-student rapport, which in turn is dependent on listening to students' views and attempts with respect, and intervening in an appropriate and constructive way" (p. 100).

In this study, S18 and S28 appear to regard the issue as one of motivational teaching strategies done by their teacher.

\section{Excerpt 6}


My teacher always helps students who find difficulties in understanding learning materials that he has explained. Besides, he always supports his students in the classroom. In that way, I feel comfortable to be in the classroom as I can write enjoyably without being afraid to make mistakes. (S18/ID6)

\section{Excerpt 7}

We can share with our teacher. She is never angry. If we still find difficulties in understanding a learning material or in our writing, she always helps us happily. She explains again the material that we still do not understand. (S28/ID7)

Dornyei (2001) also notes the importance of humor in creating the pleasant classroom atmosphere as what S21, S34, S47 observe in their classroom.

\section{Excerpt 8}

My teacher is easy going. We can consider him as our friend but also as our teacher. We can talk and joke, but we are learning too. When she taught, there will be time for her became as our teacher, gave us materials, assignments. But after that, she would make the class relaxed. We can chat about everything. She gives us time to joke with her. She likes to tell her experience. One day, she told us about her ex-boyfriend. It is more comfortable to learn something new with relax and easy going teacher rather than learn with a serious teacher. (S21/ID8)

\section{Excerpt 9}

She teaches us comfortably. In the middle of the class, she often makes jokes, and we laugh, so my class does not feel stiff. (S34/ID9)

\section{Excerpt 10}

One day, my teacher made a joke. She told us a weird fashion style in a country compared with that in American style. (S47/ID10)

To some extent, that the teachers always starts their class with friendly questions, such as "how is your night? Have you got a cup of coffee?" (S49/ID11), "can I see your smile, my students? (S19/ID12) and with an opening prayer can be other possible ways to relax the classroom atmosphere. 


\section{Excerpt 11}

In starting the class, my teacher always invites his students to pray. I feel proud of it. My other classes never start the class with a prayer. (S2/ID13)

\section{Excerpt 12}

He motivates me. He never forgets to ask the students to pray before we start our class. He also reminds the students to pray every day and go to the church. It motivates me. (S4/ID14)

A prayer in the classroom as reflected in excerpts 11 and 12 accords with Sutantoputri and Watt's $(2012$; 2013) view that religiosity becomes an important part of the students' academic life since it appears to predict their motivational goals. In Indonesia, the essence of the religiosity is highly appreciated as it becomes the first of five cores in Pancasila, the Indonesian National Philosophy; Belief in the One and Only God (Department of Foreign Affairs of the Republic of Indonesia, 1996). Overall, excerpts 8-12 may be a clear demonstration on how the teachers create a pleasant classroom climate to motivate their students in their classroom (Cheng \& Dornyei, 2007; Astuti, 2013).

Further, teachers need to encourage their students to personalize their classroom environment based on their taste, which can be done, for instance, by playing music before or after the class. S4 and S5 experience similar things in their classroom by mentioning that "my teacher plays the music when the students do the exercise, so we feel enjoy" (S4/ID15) and "my teacher sometimes plays some songs, so his students do not feel bored (S5//ID16). The written responses provide practical examples for the first layer of motivation (Rost, 2006) in which teachers can use songs in a classroom to trigger students' real interest. Also, Ur (1996) believes that some entertainment, such as jokes (as depicted in excerpts 8-10) and songs, can produce enjoyment that possibly enhances motivation.

The last motivational condition is ensuring a cohesive learner group with appropriate group norms. In this case, teachers can try to promote interaction and cooperation among their students as what S22 and S29 experience in their classroom. 


\section{Excerpt 13}

What I reflect on my teacher's teaching strategies is she uses cooperative learning approach to teaching us. She likes to divide us into a group of three or four to discuss our writing and brainstorm our ideas. It helped us a lot while we are studying in the classroom. (S22/ID17)

\section{Excerpt 14}

When my teacher asks us to write a biography, she tells us to work in a group and to discuss with our group mates to obtain detailed and broad ideas for our writing. In this case, I can exchange ideas with them and understand learning materials that my teacher has explained. (S29/ID18)

Dornyei (2001) believes that promoting cooperation among learners is motivating one as it generates less anxiety, increases one's effort to be successful in a group, and enhances his/her expectancy of success. Moreover, working in a group, as reflected in excerpts 13 and 14, can encourage broader skills of cooperation, enable various contribution from group members (Harmer, 2007), enhance motivation, contribute to a warm feeling in a classroom (Ur, 1996), and give students a more active role in their learning (Richards \& Lockhart, 1996).

Another thing that can create the motivational condition is by doing ice-breaking activities to start a class. The written responses of S5, S9, and S42 show some typical ice-breaking activities that the teachers use in their class.

\section{Excerpt 15}

Before our teacher starts the class, he always asks us to greet and smile to one another. I think it is a good idea as it can better our mood. I believe that starting a morning with a smile is a blessing for us. (S5/ID19)

\section{Excerpt 16}

He always asks us to greet and smile to our classmates (S9/ID20) 


\section{Excerpt 17}

My teacher does not directly start the lesson. One day, she sang a song. Though she looked like a child, what she did makes all students feel relaxed. (S42/ID21)

It is also necessary that teachers explicitly and clearly explain their students concerning rules of conduct in their classroom; including how the rules can enhance the learning. Yet, the data would seem to show that the participants do not reflect them as strategies that their teachers implement in their classroom.

\section{B. Generating initial motivation}

In this phase, teachers can motivate their students by promoting positive language-related values and attitudes covering intrinsic values, integrative values, and instrumental values (Dornyei, 2001). Intrinsically, teachers should raise their students' intrinsic interest to learn English by highlighting aspects of the language learning that the students can possibly enjoy, and by making the first encounter with English as positive as possible. Dealing with the integrative value, teachers should clarify positive dispositions of English language covering its culture, speakers, and influence, which can be done by sharing teachers' positive second language related experiences in their class, bringing various cultural products, such as music, videos to their class, and supplementing a course book with authentic materials. Meanwhile, instrumental values concern with explaining practical benefits that students can get when they master or are successful in learning the target language. The data (S4/ID15; S5/ID16) appears to prove that the teachers' motivational strategies are in harmony with the integrative value of their students especially by playing some songs in their class to relax the classroom atmosphere and to affirm the use of songs as a motivational instrument (Ur, 1996, Rost, 2006).

\section{Maintaining and protecting motivation}

"Motivation needs to be actively nurtured" (Dornyei, 2001, p.71). Teachers, in that case, should vary their learning tasks and make them more interesting, which can be done, as revealed in the data, by integrating supporting technologies in the classroom. For instance, S5 and S12 regard the use of learner's blogs as a motivating one. Briefly, students can use their learner blog as journals to practice their writing in which they can develop 
their sense of ownership and enjoy their practical writing experience (Campbell, 2003).

\section{Excerpt 18}

He asks us to create a blog that can be used to submit or upload our assignments. We can also express our creativity in our blog. (S5/ID22)

\section{Excerpt 19}

We use a blog, kind of a unique teaching strategy. We post, we comment to each other's post, and we beautify the blog. It motivates me because it is easy to do and fun. (S12/ID23)

\section{Excerpt 20}

My teacher sometimes asks his students to submit his assignments to their blog. He always asks us to read our classmates' work and give some comments. The activity accustoms us to speak in English and enables us to learn from each other. (S17/ID24)

Besides as a motivating technology in their class, excerpts $18-20$ can be demonstrations on how a blog is perceived as something that is fun and interesting (Yuen \& Cheung, 2013) and that can provide students "real learning opportunities to improve their written English as they were asked to read their classmates' blogs and respond to them" (Fellner \& Apple, 2006, p.17). In a sense, excerpt 20 also provides evidence on how a blog provides opportunities for students to act collaboratively in reviewing course-related materials and to review writings using the commenting feature of the blog (Duffy \& Bruns, 2006).

Facebook, a social networking site accessible throughout the world and language learning tool either inside or outside the classroom (White, 2009), is another supporting technology that helps to motivate the students. S51 clarifies that "a learning method in my classroom is also online-based. For instance, the students submit their poem to Facebook. I think Facebook can make a learning process fun and create a new learning atmosphere. Besides, every student can show his/her poem in his/her Facebook account" (S51/ID25/translated by the researcher).

Teachers should also protect their students' self-esteem and enhance their self-confidence, so they can be motivated to learn. Dornyei (2001) 
suggests teachers provide a regular experience of success for students, encourage them, reduce their language anxiety, and share learning strategies they can employ to be successful in their classroom. Some strategies revealed in the data are studying the learning materials before the class and stating points that the students write directly and explicitly as what S46 and S47 detail in their reflection.

\section{Excerpt 21}

My teacher requires her students to study the materials and to do the exercises before the class. When we have the class, we only discuss some exercises and materials that we have not understood. This saves our time. (S46/ID26)

\section{Excerpt 22}

When we write a sentence, our teacher asks us to go directly to our points and state them explicitly. She said, "you are writing in English way, not in Indonesian way. Besides, she always motivates her students to ask her questions actively, so she does not need to explain all learning materials. She always teaches us to be a confident person. (S47/ID27)

In this phase, Dornyei (2001) asserts that promoting cooperation among students becomes another way to maintain and to protect their motivation. Obviously, as reflected in the data (excerpts 14, 15, \& 21), the teachers seem to be successful in implementing this cooperative based activities to motivate their students in their classrooms.

\section{Encouraging positive retrospective self-evaluation}

The last motivational phase in Dornyei's (2001) framework encourages teachers to help their students positively deal with and reflect efforts they did their past learning experiences, so they can attribute them to something that can promote their future learning.

The data indicate that the participants do not regard reflecting their past learning experiences as something that their teachers ask them to do in the class. Nevertheless, the data shows that the teachers provide their students some feedback in a motivating way and do regular monitoring 
towards their accomplishments and progress, things that Dornyei (2001) highlights in this motivational phase. As it is clarified in the data (excerpts 6 \& 7), the teachers have concerned with the issue as what S1 and S39 similarly experience.

\section{Excerpt 23}

My teacher sometimes calls and reminds me when I make some grammatical mistakes in my sentences. I feel that I have to be able to write better using a correct grammar. I read the handout again. (S1/ID28)

\section{Excerpt 24}

My lecturer always reads our work and reminds us to pay attention to our grammar and punctuation carefully. (S39/ID29)

To sum, the discussions provide some evidence that the teachers employ motivational teaching strategies reflecting Dornyei's (2001) framework of motivational teaching practice in their EFL writing classrooms. Table 2 details the strategies.

\section{Table 2:}

The motivational teaching strategies reflected from the students' responses

\begin{tabular}{|c|c|c|}
\hline No & Motivational teaching strategies & $\begin{array}{l}\text { Ornyei's (2001) } \\
\text { framework }\end{array}$ \\
\hline 1. & starting the class with a prayer & \multirow{10}{*}{$\begin{array}{l}\text { creating basic } \\
\text { motivational } \\
\text { conditions }\end{array}$} \\
\hline 2. & $\begin{array}{l}\text { asking students to greet and smile at } \\
\text { each other }\end{array}$ & \\
\hline 3. & playing songs & \\
\hline 4. & making jokes & \\
\hline 5. & chatting with the students in the classroom & \\
\hline 6. & sharing an experience of studying abroad & \\
\hline 7. & $\begin{array}{l}\text { giving questions for each student to review the } \\
\text { learning materials }\end{array}$ & \\
\hline 8. & $\begin{array}{l}\text { walking around the class to explain a learning } \\
\text { material to a student directly and to give } \\
\text { him/her feedback }\end{array}$ & \\
\hline 9. & $\begin{array}{l}\text { calling every student to show his/her written } \\
\text { work }\end{array}$ & \\
\hline 10. & $\begin{array}{l}\text { re-explaining the learning materials that the } \\
\text { students still do not understand }\end{array}$ & \\
\hline
\end{tabular}




\begin{tabular}{|c|c|c|}
\hline 11. & asking students to work in a group & \\
\hline 12. & asking students to do a peer feedback activity & \\
\hline 13. & doing strategy 3 & $\begin{array}{l}\text { generating } \\
\text { students' } \\
\text { initial } \\
\text { motivation }\end{array}$ \\
\hline 14. & utilizing some supporting technologies & \multirow{2}{*}{$\begin{array}{l}\text { maintaining } \\
\text { and protecting } \\
\text { students' } \\
\text { motivation }\end{array}$} \\
\hline 15. & sharing learning strategies to the students & \\
\hline 16. & doing strategies $8-10$ & $\begin{array}{l}\text { encouraging } \\
\text { positive } \\
\text { students' } \\
\text { self-evaluation }\end{array}$ \\
\hline
\end{tabular}

Reinforcing Astuti's (2013) view, the study indicates that some points in Dornyei's (2001) framework do not appear in the motivational strategies mentioned in Table 1. The points are explaining rules of conduct in their classroom to enhance the learning, promoting intrinsic and instrumental values of learning to the students, encouraging students to possess positive attributions towards their past learning. Some possible reasons for the missing points endorse the facts that certain motivational strategies are different from one culture to another (Cheng \& Dornyei, 2007), that language-learning situations are various (Dornyei, 2001), and that "teaching is sometimes said to be situated and can only be understood within a particular context" (Richards, 2015, p.106). Another essential idea is that all strategies revealed in this study are felt to be attempts to create a pleasant classroom atmosphere and possess a good rapport with students, regarded as motivational teaching strategies by related literature (Gage \& Beliner, 1992, as cited in Lopez, 2011; Cheng \& Dornyei, 2007; Harmer, 2007; Astuti, 2013; Mali, 2015).

\section{E. A sample on Lesson Plan}

This part continues to implement the motivational strategies depicted in Table 1 in a sample of lesson plans that is designed, in this case, to teach how to write a paragraph as the competencies (c-d) to achieve in the writing class and that is situated within an EFL writing classroom in the Indonesian context. Therefore, I clearly understand that the strategies in the lesson plan 
may work with a teacher or a group better than another and may work better today than tomorrow because varied language learning situations are worldwide (Dornyei, 2001).

The lesson plan consists of two main parts, namely the classroom's details and teaching and learning activities, and is shown in Table 3.

Table 3:

The lesson plan

The classroom's details

(adapted from the classroom syllabus)

\begin{tabular}{|c|c|}
\hline Course/semester & Writing I/ 1 \\
\hline Academic year & $2015 / 2016$ \\
\hline Time allocation & 2 credits ( $2 \times 50$ minutes $)$ \\
\hline Competenc & $\begin{array}{l}\text { The students are to [1] identify elements of sentences and } \\
\text { paragraph writing, and [2] to write several kinds of } \\
\text { paragraphs on various topics. }\end{array}$ \\
\hline Indicators & $\begin{array}{l}\text { The students are able to [1] identify a subject and } \\
\text { controlling idea within a topic sentence; [2] to add a } \\
\text { controlling idea to a sentence; [3] to write a topic sentence } \\
\text { covering its subject and controlling idea, based on a given }\end{array}$ \\
\hline $\begin{array}{l}\text { Teaching } \\
\text { equipments }\end{array}$ & $\begin{array}{l}\text { [1] a student' handout (developed from Checkett \& } \\
\text { Checkett, 2010; Langan, 2011); [2] a laptop; [3] a projector } \\
\text { [4] a set of speakers; [5] a white board; } \\
\text { [6] two board markers; [7] students' blog }\end{array}$ \\
\hline
\end{tabular}

\begin{tabular}{lll}
\hline \multicolumn{2}{l}{ Teaching and learning activities } & \\
\hline No & Activities & $\begin{array}{l}\text { Time } \\
\text { allocation }\end{array}$ \\
\cline { 1 - 2 } A. & Pre-class activities & \multirow{2}{*}{$10 ”$} \\
\cline { 1 - 2 } 1. & The teacher comes earlier to the class. & \\
\cline { 1 - 2 } 2. & The teacher prepares his/her teaching equipments. & \\
\cline { 1 - 2 } 3. & The teacher plays songs while waiting for his/her students. &
\end{tabular}

B. Opening activities 
80 Celt: A Journal of Culture, English Language Teaching and Literature,

Volume 17, Number 1, July 2017, pp. 60 - 85

\begin{tabular}{cl}
\hline 4. & The teacher stops the songs and is ready to start the class. \\
\hline 5. & $\begin{array}{l}\text { The teacher asks a student to lead and opening prayer } \\
\text { based on his/her belief. }\end{array}$ \\
\hline 6. & $\begin{array}{l}\text { The teacher greets all students. (e.g. by asking the progress } \\
\text { of his/her study; whether they have got their breakfast, and } \\
\text { other related things) }\end{array}$ \\
7. The teacher asks all students to smile and greet one \\
another.
\end{tabular}

\section{Main activities}

8. The teacher asks students to work in a group of three-four students.

The teacher asks students to brainstorm definitions and

9. related ideas of a paragraph and a topic sentence in their group.

\begin{tabular}{|c|c|c|}
\hline 10. & $\begin{array}{l}\text { The teacher asks every group to share their ideas by writing } \\
\text { them on the whiteboard. }\end{array}$ & \multirow{11}{*}{$90 ”$} \\
\hline 11. & $\begin{array}{l}\text { The teacher summarizes their ideas and displays them on } \\
\text { the projector. }\end{array}$ & \\
\hline 12. & $\begin{array}{l}\text { The teacher explains ideas in a paragraph, and a topic } \\
\text { sentence stated in the handout. }\end{array}$ & \\
\hline 13. & The teacher asks their students to stay in their group. & \\
\hline 14. & $\begin{array}{l}\text { The teacher asks them to do exercises in their handout } \\
\text { (adapted from Checkett \& Checkett, 2010, p.135-137); } \\
\text { asking them to achieve the indicators [1-3] }\end{array}$ & \\
\hline 15. & $\begin{array}{l}\text { The teacher asks them to discuss their answers with their } \\
\text { group mates and to provide some necessary feedback to } \\
\text { one another. }\end{array}$ & \\
\hline 16. & $\begin{array}{l}\text { The teacher plays some songs while they are doing the } \\
\text { exercises. }\end{array}$ & \\
\hline 17. & $\begin{array}{l}\text { The teacher walks around the class to participate in the } \\
\text { discussions. }\end{array}$ & \\
\hline 18. & The teacher may chat with some group members. & \\
\hline 18. & $\begin{array}{l}\text { The teacher reads their work and provides some necessary } \\
\text { feedback. }\end{array}$ & \\
\hline 19. & $\begin{array}{l}\text { The teacher may suggest some strategies to write a good } \\
\text { topic sentence. }\end{array}$ & \\
\hline
\end{tabular}

D. Closing activities 


\begin{tabular}{ll}
\hline 20. & $\begin{array}{l}\text { The teacher tells the students to be ready for the exercises } \\
\text { in the following meeting as they will discuss them. }\end{array}$ \\
\hline 21. & $\begin{array}{l}\text { The teacher tells the students to post questions to the blog } \\
\text { in case they find difficulties in completing the tasks. }\end{array}$ \\
\hline 22. & $\begin{array}{l}\text { The teacher asks a student to lead a closing prayer based on } \\
\text { his/her belief. }\end{array}$ \\
\hline 23. & $\begin{array}{l}\text { The teacher greets all students and reminds them to pray } \\
\text { everyday and to thank their parents. }\end{array}$ \\
\hline 24. & The teacher allows them to leave the class. \\
\hline 25. & $\begin{array}{l}\text { The teacher stays for some minutes in case there are some } \\
\text { students plan to consult with him/her personally. }\end{array}$ \\
\hline 26. & The teacher leaves the class. \\
\hline
\end{tabular}

\section{CONCLUSION}

The current study has provided clear and practical illustrations on what the teachers did to motivate their students to write in their EFL writing classrooms. Obviously, the study confirms an idea that teachers can motivate their students to learn (Dornyei \& Csizer, 1998; Chambers, 1999 in Dornyei, 2001; Oxford, 1998 in Dornyei \& Ushioda, 2001; Harmer, 2007; Mali, 2015) and an underlying assumption that they use strategies to motivate their students (Astuti, 2013). Strategies such as creating a relaxed atmosphere in a classroom (Gage \& Beliner, 1992, p.480-485, as cited in Lopez, 2011; Cheng \& Dornyei, 2007, Astuti, 2013) and possessing a good rapport with students (Harmer, 2007; Mali, 2015) would seem to enhance the students' motivation in the context of Indonesian EFL writing classrooms and, therefore, to be considered as motivational strategies that possibly work in multicultural settings. Nevertheless, EFL teachers still need to make necessary adjustment on the strategies discussed in this current study to make them work based on to their classroom contexts. To what extent each motivational component as discussed in Dornyei's (2001) framework can motivate students better remains a mystery and, therefore, subjects to a further investigation. Admitting the limited number of the research participants and the teachers to involve, I believe that the findings of the current study remain inconclusive. Thus, I encourage future studies to explore other possible motivational teaching strategies reflected from a larger group of participants and teachers as well as from settings that are more diverse. Finally, this study hopes to provide insights for EFL teachers espousing similar teaching practices to enhance their students' motivation, particularly in their EFL writing classrooms. 


\section{REFERENCES}

Al-Mahrooqi, R., Abrar-ul-Hassan, S. \& Asante, C. (2012). Analyzing the use of motivational strategies by EFL teachers in Oman. Malaysian Journal of ELT Research, 8(1), 36-76.

Alsayed, M. (2003). Factors that contribute to success in learning English as a foreign language. Damascus University Journal, 19 (1+2), 21-44.

Ary, D., Jacobs, L.C., \& Sorensen, C. (2010). Introduction to research in education. Belmont: Wadsworth, Cengage Learning.

Astuti, S.P. (2013). Teachers' and students' perceptions of motivational teaching strategies in an Indonesian high school context. TEFLIN Journal, 24 (1), 14-31.

Campbell, A.P. (2003). Weblogs for use with ESL classes. The Internet TESL Journal, 9 (2). Retrieved November $20^{\text {th }}, 2014$, from http://iteslj.org/ Techniques/Campbell-Weblogs.html

Checkett, G,F., \& Checkett, L. (2010). The write start: Sentences to paragraphs with professional and student readings $\left(4^{\text {th }}\right.$ ed.). Boston: Wadsworth, Cengage Learning.

Cheng, H.F., \& Dornyei, Z. (2007). The use of motivational strategies in language instruction: The case of EFL teaching in Taiwan. Innovation in Language Learning and Teaching, 1 (1), 153-173.

Cohen, L., Manion, L., \& Morrison, K. (2007). Research methods in education. New York: Routledge.

Creswell, J.W. (2007). Qualitative inquiry and research design: Choosing among five approaches ( $2^{\text {nd }}$ ed.). London: Sage Publications, Inc.

Department of Foreign Affairs of the Republic of Indonesia. (1996). Pancasila the State of Philosopy. Retrieved November 17 $7^{\text {th }}$, 2015, from: http://www.geocities.jp/indo_ka/const/ri.htm\#pancasila

Dornyei, Z \& Ushioda, E. (Eds.) (2001). Teaching and researching motivation $\left(2^{\text {th }}\right.$ ed.). Harlow: Pearson Education Limited. 
Mali, Y.C.G. Motivational Teaching Strategies in Indonesian EFL Writing

Classroom

Dornyei, Z. (1994). Motivation and motivating in the foreign language classroom. The Modern Language Journal, 78 (3), 273-284.

Dornyei, Z. (2001). Motivational strategies in the language classroom. Cambridge: Cambridge University Press.

Dornyei, Z., \& Csizer, K. (1998). Ten commandments for motivating language learners: results of an empirical study. Language Teaching Research 2(3), 203_229.

Duffy, P., \& Bruns, A. (2006). The use of blogs, wikis, and RSS in education: a conversation of possibilities. In Proceedings Online Learning and Teaching Conference 2006 Brisbane, 31-38, Retrieved November 22 ${ }^{\text {nd }}$, 2014, from http://eprints.qut.edu.au/5398/1/5398.pdf

Ellis, R. (1994). The study of second language acquisition. Oxford: Oxford University Press.

Fellner, T., \& Apple, M. (2006). Developing writing fluency and lexical complexity with blogs. The JALT CALL Journal, 2(1), 15-26.

Gass, S.M \& Selinker, L. (2001). Second language acquisition: An introductory course ( $2^{\text {nd }}$ ed). New Jersey: Lawrence Erlbaum Associates.

Harmer, J. (2007). The practice of English language teaching. Essex: Pearson Education Limited.

Hughey, J.B., Wormuth, D.R., Hartfiel, V.F., \& Jacobs, H.L. (1983). Teaching ESL composition; Principles and techniques Cambridge: Newbury House Publishers.

Kassing, R.B. (2011). Perceptions of motivational teaching strategies in an EFL classroom: The case of a class in a private university in Indonesia. M.Ed thesis, Victoria University of Wellington.

Khamkhien, A. (2010). Factors affecting language learning strategy reported usage by Thai and Vietnamnese EFL learners. Electronic Journal of Foreign Language Teaching, 7(1), 66-85.

Kimura, Y., Nakata, Y., \& Okumura, T. (2000). Language learning motivation of EFL learners in Japan-A cross sectional analysis of various learning milieus. JALT Journal, .47-65. 
84 Celt: A Journal of Culture, English Language Teaching and Literature, Volume 17, Number 1, July 2017, pp. 60 - 85

Lamb, M., \& Wedell, M. (2013). Inspiring English teachers: A comparative study of learner perceptions of inspirational teaching. London: British Council.

Langan, J. (2011). College writing skills and college writing skills with readings $\left(8^{\text {th }}\right.$ ed.). New York: McGraw-Hill.

Lifrieri, V. (2005). A sociological perspective on motivation to learn EFL: The case of Escuelas Plurilingues in Argentina. M.A thesis, University of Pittsburgh.

Lopez, M.G.M. (2011). The motivational properties of emotions in Foreign Language Learning. Colomb.Appl.Linguist.J, (13) 2, 43-59.

Mali, Y.C.G.(2015). Motivational factors in the Indonesian EFL writing classroom. Bahasa Eु Sastra, 15 (2), 1-10.

Malilang, C.S. (2013). How children decode visual narrative in Gaiman's and McKean's The Wolves in the Walls. Resital, 14 (1), 81-90.

McDonough, S. (1983). Psychology in foreign language teaching. George Allen \& Unwin: London.

Neuman, W.L. (2006). Social research methods qualitative and quantitative approaches (6th ed.). Boston: Pearson.

Reid, G. (2007). Motivating learners in the classroom: ideas and strategies. London: Paul Champman Publishing.

Richards, J.C. (2015). Key issues in language teaching. Cambridge: Cambridge University Press.

Richards, J.C., \& Lockhart, C. (1996). Reflective teaching in second language classrooms. Cambridge: Cambridge University Press.

Richards, J.C., \& Schmidt, R. (2010). Longman dictionary of language teaching and applied linguistics ( $4^{\text {th }}$ ed.). Harlow: Pearson Education Limited.

Rost, M. (2006). Generating student motivation. Retrieved December $14^{\text {th }}$, 2015, from http://www.pearsonlongman.com/ae/worldview/ motivation.pdf 
Mali, Y.C.G. Motivational Teaching Strategies in Indonesian EFL Writing

Classroom

Sawir, E. (2005). Language difficulties of international students in Australia: The effects of prior learning experience. International Education Journal, 6 (5), 567-580.

Schunk, D.H., Pintrich, P.R., \& Meece, J.L. (2008). Motivation in education: Theory, research, and applications. New Jersey: Pearson Education, Inc.

Sutantoputri, N.W \& Watt, H.M.G. (2012). Attribution and motivation: A cultural study among Indonesian university students. International Journal of Higher Education, 1 (2), 118-129.

Sutantoputri, N.W \& Watt, H.M.G. (2013). Attribution and motivation: Gender, ethnicity, and religion differences among Indonesian university students. International Journal of Higher Education, 2 (1), 12-21.

Tran, L.T. (2007). Learners' motivation and identity in the Vietnamese EFL writing classroom. English Teaching: Practice and Critique, 6 (1), 151-163.

Ur, P. (1996). A course in language teaching. Cambridge: Cambridge University Press.

White, F.D. (1986). The writer's art: A practical rhetoric and handbook. California: Wadsworth.

White, J. (2009). The Use of Facebook to Improve Motivation and Academic Writing. Retrieved October $17^{\text {th }}, 2014$, from http://wirelessready.nucba. ac.jp/white2009.pdf.

Yuen, G.O.M., \& Cheung, W.S. (2013). What students like and dislike about blogs: A two-case study. New Horizons in Education, 61 (2), 93-110. Retrieved December $14^{\text {th }}, 2014$, from_http://www.nus.edu.sg/celc/ publications/RETL62/01to20blackstone.pdf 